\title{
PENGARUH PENAMBAHAN SARI BUAH NAGA MERAH (Hylocereus polyrhizus) TERHADAP AKTIVITAS ANTIOKSIDAN DAN KARAKTERISTIK FISIKOKIMIA CASPIAN SEA YOGHURT
}

\section{Addition Effect of Red Dragon Fruit (Hylocereus polyrhizus) to Antioxidant Activity and Physicochemical Characteristic of Caspian Sea Yoghurt}

\author{
Hana Susanti Maleta*, Joni Kusnadi \\ 1Jurusan Teknologi Hasil Pertanian - FTP Universitas Brawijaya Malang \\ JI. Veteran, Malang 65145 \\ *Email korespondensi : hanamaleta@gmail.com
}

\begin{abstract}
ABSTRAK
Buah naga merah merupakan salah satu buah yang dapat ditambahkan kedalam yoghurt karena memiliki kandungan antioksidan. Penelitian ini bertujuan untuk mengetahui pengaruh penambahan sari buah naga merah terhadap karakteristik Caspian Sea yoghurt. Penelitian ini menggunakan metode Rancangan Acak Lengkap (RAL) Faktorial dengan 2 faktor. Faktor I adalah konsentrasi sari buah naga merah (10\%,15\%, 20\%). Faktor II adalah lama penyimpanan ( 0 hari, 4 hari, 8 hari, 12 hari). Hasil penelitian dianalisis dengan Analysis of Variance (ANOVA). Perlakuan terbaik Caspian Sea yoghurt diperoleh berdasarkan metode multiple attribute Zeleny. Data organoleptik dianalisi menggunakan Hedonic Scale Scoring. Perlakuan terbaik Caspian Sea yoghurt buah naga merah adalah konsentrasi $10 \%$ dan lama penyimpanan 0 hari. Caspian Sea yoghurt perlakuan terbaik memiliki pH 4.13, total asam $0.15 \%$, aktivitas antioksidan $25.68 \%$, konsentrasi betasianin $1.10 \mathrm{mg} / 100 \mathrm{~g}$, total bakteri asam laktat $5.17 \mathrm{log} \mathrm{cfu} / \mathrm{ml}$, viskositas $386.7 \mathrm{cP}$, total padatan terlarut $6.13^{\circ} \mathrm{brix}$, nilai kecerahan $\left(\mathrm{L}^{*}\right)$ 64.33, nilai kemerahan $\left(a^{*}\right) 34.80$, nilai kekuningan $\left(b^{*}\right)-8.67$.
\end{abstract}

Kata kunci: Aktivitas Antioksidan, Buah Naga Merah, Caspian Sea Yoghurt

\section{ABSTRACT}

Red dragon fruit is one of the fruits that can be added since it has antioxidant activity. The purpose of this research is to know the effect of red dragon fruit on the properties of Caspian Sea yogurt. Complete Randomized Design (RAL) Factorial with two factors used in this research. The first factor is the concentration of red dragon fruit (10\%, 15\%, 20\%) and the second factor is storage time ( 0 days, 4 days, 8 days, 12 days). The data was determined by using Analysis of Variance (ANOVA). The best treatment of Caspian Sea yogurt is determined with multiple attribute Zeleny method. The organoleptic properties of Caspian Sea yogurt were tested with Hedonic Scale Scoring method. The best treatment of Caspian Sea yogurt red dragon fruit was a concentration of $10 \%$ and storage time of 0 days that cointains $4.13 \mathrm{pH}, 0.15 \%$ total acid, 25.68\% antioxidant activity, $1.10 \mathrm{mg} / 100 \mathrm{~g}$ betacyanin content, 5.17 log cfu/ml total lactic acid bacteria, $386.7 \mathrm{cP}$ viscosity, $6.13^{\circ} \mathrm{brix}$ total dissolved solids, 64.33 lightness $\left(L^{*}\right), 34.80$ redness $\left(a^{*}\right),-8.67$ yellowness $\left(b^{*}\right)$.

Keywords: Antioxidant activity, Caspian Sea Yoghurt, Red Dragon Fruit

\section{PENDAHULUAN}

Yoghurt merupakan salah satu produk yang dihasilkan dari proses fermentasi pada susu. Yoghurt di fermentasi menggunakan bakteri Lactobacillus bulgaricus dan Streptococcus thermophilus. Yoghurt memiliki banyak manfaat bagi tubuh seperti menekan pertumbuhan mikroorganisme patogen di saluran pencernaan. Selain itu, selama fermentasi akan terjadi 
pemecahan laktosa menjadi asam laktat sehingga yoghurt aman dikonsumsi bagi yang memiliki lactose intolerance (Gianti dan Herly, 2011).

Caspian Sea yoghurt merupakan salah satu jenis yoghurt yang di fermentasi menggunakan bakteri Lactococcus lactis sp. cremoris dan Acetobacter orientalis. Hasil dari fermentasi kedua bakteri tersebut yaitu menghasilkan yoghurt dengan keasaman yang rendah dan viskositas yang tinggi. Fermentasi Caspian Sea yoghurt dilakukan pada suhu kamar (25300C) (Kiryu et al., 2009).

Semakin berkembangnya jaman yogurt memiliki beberapa tipe, salah satunya adalah fruit yogurt. Fruit yogurt merupakan yoghurt yang ditambahkan sari buah. Penambahan sari buah kedalam yoghurt dapat menambah nutrisi (Mahmood et al., 2008). Salah satu buahbuahan yang dapat ditambahkan kedalam yoghurt yaitu buah naga merah (Hylocereus polyrhizus). Buah naga merah (Hylocereus polyrhizus) merupakan salah satu buah yang memiliki kandungan antioksidan. Kandungan antioksidan pada buah naga merah yaitu vitamin $\mathrm{C}$, flavonoid, betasianin dan karotenoid. Antioksidan tersebut mencegah pembentukan radikal bebas penyebab kanker (Choo dan Yong, 2011). Antioksidan merupakan senyawa yang mendonorkan satu elektronnya ke radikal bebas sehingga aktivitas radikal bebas bisa dihambat (Winarsi, 2007).

Penambahan buah naga merah pada pembuatan Caspian Sea yoghurt diharapkan dapat meningkatkan aktivitas antioksidan pada produk. Penelitian sebelumnya menyatakan bahwa penambahan buah naga merah sebesar 30\% ke dalam yoghurt dapat meningkatkan aktivitas antioksidan sebesar 45,74\% (Zainoldin dan Baba, 2009). Selain itu, lama penyimpanan dapat menentukan kualitas produk. Semakin lama disimpan, kualitas produk akan semakin menurun. Kerusakan yang dapat terjadi selama masa penyimpanan yaitu terjadinya wheying off atau terpisahnya emulsi dan tumbuhnya kapang pada permukaan yoghurt, sehingga dapat menurunkan kualitas yoghurt. Penelitian terdahulu menyatakan bahwa yoghurt dengan penambahan rosella pada suhu rendah masih dapat dikonsumsi setelah 15 hari penyimpanan (Sri, 2016). Penambahan sari buah naga merah pada Caspian Sea yoghurt dan lama penyimpanan Caspian Sea yoghurt diharapkan mampu menghasilkan Caspian Sea yoghurt yang baik ditinjau dari aktivitas antioksidan, sifat fisik, kimia, mikrobiologi, dan organoleptik Caspian Sea yoghurt.

\section{BAHAN DAN METODE}

\section{Alat}

Alat yang digunakan untuk pembuatan Caspian Sea yoghurt adalah timbangan digital (Ohaus), peralatan gelas, termometer, gelas ukur, blender, dan kompor listrik (Maspion). Peralatan yang digunakan untuk analisis adalah $\mathrm{pH}$ meter (Hanna), autoklaf (Tomy), inkubator (Binder), tabung reaksi, cawan petri, erlenmeyer, labu ukur, Laminar Air Flow (Magnehelix), mikropipet (Gilson), vorteks, pipet ukur, pipet tetes, bunsen, gelas ukur, gelas beker, bola hisap, buret, corong, kertas saring, timbangan analitik (Ohaus), colony counter (BZG 30), shaker waterbath (Memmert), sentrifuse (EBA 20 Heltich), dan spektrofotometer (Thermoscientific).

\section{Bahan}

Bahan yang digunakan dalam pembuatan Caspian Sea yoghurt adalah Buah naga merah diperoleh dari pasar Merjosari, Malang, susu pasteurisari "Diamond", dan strarter bubuk Caspian Sea yoghurt "Kasupi umi (kai) yoguruto" mengandung Lactococcus lactis ssp. cremoris dan Acetobacter orientalis. Bahan yang digunakan untuk analisis adalah aquades, buffer $\mathrm{pH} 4$ dan $\mathrm{pH} 7$, indikator $\mathrm{PP}, \mathrm{NaOH} 0,1 \mathrm{~N}$, media MRSA (Merck), pepton, alkohol $70 \%$, etanol 95\%, reagen DPPH 0,2 mM dalam etanol, dan kertas saring halus.

\section{Metode Penelitian}

Penelitian menggunakan Rancangan Acak Lengkap (RAL) faktorial. Faktor I adalah konsentrasi sari buah naga merah dengan konsentrasi 10\%, 15\%, dan $20 \%$. Faktor II adalah lama penyimpanan Caspian Sea yoghurt selama 0 hari, 4 hari, 8 hari, dan 12 hari. Kedua 
Faktor tersebut menghasilkan 12 kombinasi perlakuan dengan 3 kali ulangan sehingga dihasilkan 36 satuan percobaan.

\section{Pembuatan Sari Buah Naga Merah}

Buah naga merah dikupas kulitnya dan dipotong, selanjutnya dihancurkan menggunakan blender. Buah naga merah yang telah dihancurkan, kemudian disaring menggunakan kain saring. Hasil penyaringan, selanjutnya dipasteurisasi pada suhu $40^{\circ} \mathrm{C}$ selama 30 menit lalu didinginkan hingga suhu $30^{\circ} \mathrm{C}$.

\section{Pembuatan Starter Caspian Sea Yoghurt}

30 gram starter bubuk Caspian Sea yoghurt diinokulasikan ke dalam $500 \mathrm{ml}$ susu pasteurisasi. Selanjutnya diinkubasi pada suhu $30^{\circ} \mathrm{C}$ selama 18 jam di dalam inkubator.

\section{Pembuatan Caspian Sea Yoghurt Buah Naga Merah}

Sari buah naga merah berbagai konsentrasi (10\%, 15\%, dan 20\%) dimasukkan ke dalam susu pasteurisasi, kemudian starter Caspian Sea yoghurt sebanyak 10\% diinokulasikan ke dalam campuran susu dan sari buah naga merah. Campuran tersebut selanjutnya diinkubasi pada suhu $30^{\circ} \mathrm{C}$ selama 18 jam di dalam inkubator. Setelah 18 jam, Caspian Sea yoghurt buah naga merah disimpan dalam kulkas suhu $5^{\circ} \mathrm{C}$ selama 4 , 8, dan 12 hari.

\section{Analisis Kimia}

Bahan baku buah naga merah dianalisis aktivitas antioksidan (Tranggono dkk., 1990) dan konsentrasi betasianin (Nurul dan Asmah, 2014). Produk Caspian Sea yoghut buah naga merah dianalisis total bakteri asam laktat (Lay, 1994), $\mathrm{pH}$ (AOAC, 1990), total asam (AOAC, 1995), aktivitas antioksidan (Tranggono dkk., 1990), konsentrasi betasianin (Nurul dan Asmah, 2014), viskositas, (Modifikasi Yuwono dan Susanto, 1998), total padatan terlarut (Apriyantono dkk., 1989), warna $\mathrm{L}^{*}, \mathrm{a}^{*}, \mathrm{~b}^{*}$ (Yuwono dan Susanto, 1998), dan uji hedonik untuk parameter organoleptik (Watts et al., 1989).

\section{Analisis Statistika}

Data diolah menggunakan ANOVA dengan aplikasi Minitab 16. Hasil ANOVA yang telah diperoleh diuji lanjut menggunakan uji BNT (Beda Nyata Terkecil) apabila terdapat perbedaan nyata $(\alpha=0,05)$.

\section{HASIL DAN PEMBAHASAN}

\section{Aktivitas Antioksidan dan Konsentrasi Betasianin dalam Bahan Baku}

Aktivitas antioksidan dan konsentrasi betasianin dalam buah naga merah ditampilakan pada Tabel 1. Pada analisis bahan baku terhadap aktivitas antioksidan didapatkan hasil sebesar $21.4 \%$. Menurut Purwanti (2015) aktivitas antioksidan pada sari buah naga merah sebesar $20.7 \%$. Buah naga merah mengandung senyawa-senyawa seperti fenol, flavonoid, betasianin, dan vitamin C yang memiliki kemampuan sebagai antioksidan, sehingga saat dilakukan pengukuran aktivitas antioksidan senyawa-senyawa tersebut ikut terukur. Aktivitas antioksidan yang terukur terdapat perbedaan dengan literatur, hal tersebut dapat dikarenakan metode yang digunakan untuk analisis berbeda.

Tabel 1. Analisis bahan baku sari buah naga merah segar (Hylocereus polyrhizus)

\begin{tabular}{lcc}
\hline \multicolumn{1}{c}{ Parameter } & Analisis & Literatur \\
\hline Aktivitas Antioksidan (\%) & $21.4 \pm 0.86$ & $20.7 \pm 0.35^{\star}$ \\
Betasianin (mg/100g) & $14.4 \pm 0.05$ & $10.3 \pm 0.22^{\star *}$ \\
\hline
\end{tabular}

Sumber: Purwanti, 2015*, Wu et al., 2006** 
Betasianin merupakan suatu pigmen warna red-violet yang terdapat dalam buah naga merah. Konsentrasi betasianin pada bahan baku buah naga merah sebesar $14.4 \mathrm{mg} / 100 \mathrm{~g}$. Menurut Wu et al. (2006) konsentrasi betasianin buah naga merah sebesar $10.3 \mathrm{mg} / 100 \mathrm{~g}$. Menurut Phebe et al. (2009) konsentrasi betasianin dipengaruhi oleh tingkat kematangan buah naga merah. Buah naga merah yang di panen pada hari ke-25 memiliki konsentrasi betasianin sebesar $10-12 \mathrm{mg} / 100 \mathrm{~g}$ sedangkan buah naga merah yang di panen pada hari ke-35 memiliki konsentrasi betasianin sebesar 35-37 mg/ $100 \mathrm{~g}$.

\section{Total Bateri Asam Laktat Caspian Sea Yoghurt Buah Naga Merah}

Total bakteri asam laktat dalam Caspian Sea yoghurt buah naga merah ditampilkan pada Tabel 2. Total bakteri asam laktat Caspian Sea yoghurt dengan perlakuan penambahan sari buah naga merah dan lama penyimpanan berkisar antara 4.74-5.67 log cfu/ml.

Tabel 2. Rerata Total Bakteri Asam Laktat Caspian Sea Yoghurt Buah Naga Merah

\begin{tabular}{ccc}
\hline $\begin{array}{c}\text { Lama } \\
\text { Penyimpanan }\end{array}$ & Konsentrasi Sari Buah Naga & $\begin{array}{c}\text { Rerata Total Bakteri Asam Laktat } \\
\text { (log cfu/ml) }\end{array}$ \\
\hline \multirow{2}{*}{0 hari } & $10 \%$ & $5.17 \pm 0.20$ \\
& $15 \%$ & $5.49 \pm 0.23$ \\
\multirow{2}{*}{4 hari } & $20 \%$ & $5.67 \pm 0.23$ \\
& $10 \%$ & $5.14 \pm 0.31$ \\
\multirow{2}{*}{8 hari } & $15 \%$ & $5.40 \pm 0.16$ \\
& $20 \%$ & $5.62 \pm 0.28$ \\
\multirow{2}{*}{12 hari } & $10 \%$ & $5.11 \pm 0.22$ \\
& $15 \%$ & $4.87 \pm 0.17$ \\
& $10 \%$ & $5.38 \pm 0.34$ \\
& $15 \%$ & $4.74 \pm 0.39$ \\
& $20 \%$ & $4.82 \pm 0.14$ \\
\end{tabular}

Rerata total bakteri asam laktat Caspian Sea yoghurt akan meningkat dengan semakin tingginya penambahan konsentrasi sari buah naga merah, namun rata-rata total bakteri asam laktat cenderung menurun pada perlakuan lama penyimpanan. Semakin tinggi konsentrasi, maka total bakteri asam laktat Caspian Sea yoghurt sari buah naga merah yang dihasilkan akan semakin meningkat. Hal ini dapat dikarenakan adanya gula-gula sederhana yang terdapat dalam buah naga merah yang mudah dimanfaatkan bakteri asam laktat, sehingga aktivitas bakteri asam laktat juga meningkat (Kumalasari dkk, 2013).

Semakin lama waktu penyimpanan, maka total bakteri asam laktat Caspian Sea yoghurt sari buah naga merah yang dihasilkan akan semakin menurun. Jumlah bakteri asam laktat dipengaruhi oleh ketersediaan substrat dalam media. Pada waktu tertentu jumlah substrat dalam susu fermentasi tersedia dalam jumlah yang cukup banyak sehingga mendorong bakteri untuk aktif memperbanyak diri, namun suatu saat jumlah substrat semakin menurun sehingga bakteri tidak aktif lagi memperbanyak diri (Sunarlim dan Usmiati, 2006). Selain itu, selama penyimpanan sel bakteri dapat mengalami lisis sehingga saat dihitung jumlah bakteri lebih sedikit (Usmiati, 2011). Hal tersebut dikarenakan buah naga merah mengandung senyawa flavonoid yang memiliki sifat antibakteri yang dapat merusak sel sehingga jumlahnya akan menurun.

\section{Karakteristik Kimia Caspian Sea Yoghurt Buah Naga Merah}

Karakteristik kimia Caspian Sea yoghurt, berupa $\mathrm{pH}$, total asam, aktivitas antioksidan, dan konsentrasi betasianin ditampilkan pada Tabel 3.

1. $\mathrm{pH}$

$\mathrm{pH}$ Caspian Sea yoghurt dengan perlakuan penambahan sari buah naga merah dan lama penyimpanan berkisar antara 4.13-4.02. Rerata nilai $\mathrm{pH}$ yoghurt dengan penambahan 
sari buah naga merah dan lama penyimpanan mengalami penurunan. Menurut Setianto (2014) bakteri asam laktat menamfaatkan monosakarida-monosakarida yang terkandung dalam sari buah naga merah selama fermentasi berlangsung, sehingga terbentuk asam laktat yang membuat suasana menjadi asam dan $\mathrm{pH}$ turun. Oleh karena itu, semakin tinggi penambahan konsentrasi sari buah naga merah dapat menurunkan $\mathrm{pH}$. Paseephol et al (2009) menambahkan selama penyimpanan terjadi penurunan $\mathrm{pH}$ yang ditunjukkan dengan meningkatnya rasa asam pada yogurt.

Tabel 3. Rerata pH, Total Asam, Aktivitas Antioksidan, dan Konsentrasi Betasianin Caspian Sea Yoghurt Buah Naga Merah

\begin{tabular}{cccccc}
\hline $\begin{array}{c}\text { Lama } \\
\text { Penyim } \\
\text { panan }\end{array}$ & $\begin{array}{c}\text { Konsent } \\
\text { rasi Sari } \\
\text { Buah } \\
\text { Naga }\end{array}$ & Rerata pH & $\begin{array}{c}\text { Rerata Total } \\
\text { Asam (\%) }\end{array}$ & $\begin{array}{c}\text { Rerata } \\
\text { Aktivitas } \\
\text { Antioksidan } \\
(\%)\end{array}$ & $\begin{array}{c}\text { Rerata } \\
\text { Konsentrasi } \\
\text { Betasianin } \\
\text { (mg/100g) }\end{array}$ \\
\hline \multirow{2}{*}{ h hari } & $10 \%$ & $4.13 \pm 0.01$ & $0.15 \pm 0.02$ & $25.68 \pm 1.19$ & $1.103 \pm 0.155$ \\
& $15 \%$ & $4.12 \pm 0.03$ & $0.25 \pm 0.02$ & $31.49 \pm 1.30$ & $1.977 \pm 0.206$ \\
& $20 \%$ & $4.10 \pm 0.01$ & $0.33 \pm 0.02$ & $53.70 \pm 1.37$ & $2.773 \pm 0.117$ \\
4 hari & $10 \%$ & $4.11 \pm 0.01$ & $0.16 \pm 0.01$ & $27.66 \pm 1.70$ & $1.153 \pm 0.124$ \\
& $15 \%$ & $4.09 \pm 0.08$ & $0.41 \pm 0.01$ & $32.22 \pm 1.61$ & $2.517 \pm 0.133$ \\
& $20 \%$ & $4.08 \pm 0.02$ & $0.42 \pm 0.01$ & $58.09 \pm 1.57$ & $3.140 \pm 0.106$ \\
8 hari & $10 \%$ & $4.10 \pm 0.01$ & $0.25 \pm 0.01$ & $29.38 \pm 0.41$ & $1.713 \pm 0.035$ \\
& $15 \%$ & $4.08 \pm 0.03$ & $0.43 \pm 0.05$ & $38.82 \pm 1.14$ & $3.023 \pm 0.110$ \\
& $20 \%$ & $4.06 \pm 0.01$ & $0.49 \pm 0.08$ & $59.04 \pm 1.82$ & $3.390 \pm 0.167$ \\
12 hari & $10 \%$ & $4.09 \pm 0.06$ & $0.33 \pm 0.22$ & $24.55 \pm 1.66$ & $1.507 \pm 0.057$ \\
& $15 \%$ & $4.04 \pm 0.06$ & $0.44 \pm 0.05$ & $36.42 \pm 1.05$ & $1.887 \pm 0.202$ \\
& $20 \%$ & $4.02 \pm 0.01$ & $0.56 \pm 0.01$ & $53.69 \pm 1.26$ & $2.837 \pm 0.194$ \\
\hline
\end{tabular}

\section{Total Asam}

Total asam Caspian Sea yoghurt dengan perlakuan penambahan sari buah naga merah dan lama penyimpanan berkisar antara $0.15-0.56 \%$. Rerata nilai total asam yoghurt dengan penambahan sari buah naga merah dan lama penyimpanan mengalami kenaikan. Penambahan sari buah naga merah akan meningkatkan jumlah karbohidrat, semakin tinggi karbohidrat maka pemecahan laktosa dan gula-gula lain menjadi asam laktat oleh bakteri asam laktat meningkat (Legowo, dkk., 2009). Oleh karena itu, ketersediaan sumber nutrisi yang lebih banyak akan dimanfaatkan oleh bakteri asam laktat selama fermentasi, sehingga metabolit akhir berupa asam laktat akan meningkat. Menurut Usmiati (2011) produk susu fermentasi yang disimpan masih menunjukkan aktivitas fermentasi menghasilkan asam laktat sehingga total asam tertitrasi akan semakin meningkat, namun suatu saat dapat terjadi reaksi metabolisme lebih lanjut yang memungkinkan terjadinya perubahan asam laktat menjadi senyawa sekunder sehingga tidak terukur sebagai nilai asam tertitrasi lagi.

\section{Aktivitas Antioksidan}

Aktivitas antioksidan pada Caspian Sea yoghurt dengan perlakuan penambahan sari buah naga merah dan lama penyimpanan berkisar antara $24.55-59.04 \%$. Rerata nilai aktivitas antioksidan yoghurt akan meningkat dengan semakin tingginya penambahan konsentrasi sari buah naga merah, namun rerata nilai aktivitas antioksidan yoghurt cenderung menurun dengan semakin lamanya waktu penyimpanan. sari buah naga merah mengandung aktivitas antioksidan yang tinggi sehingga semakin tinggi konsentrasi buah naga merah yang ditambahkan maka aktivitas antioksidan Caspian Sea yoghurt juga akan semakin meningkat. Menurut Zhang (2011) peningkatan aktivitas antioksidan juga berkaitan dengan peningkatan total bakteri asam laktat yang memiliki aktivitas antioksidan yang tinggi. Bakteri asam laktat tersebut memiliki kemampuan untuk memecah protein menjadi peptida-peptida (bioactive peptides) (Virtanen, 2006). 


\section{Konsentrasi Betasianin}

Konsentrasi betasianin Caspian Sea yoghurt dengan perlakuan penambahan sari buah naga merah dan lama penyimpanan berkisar antara $1.103-3.390 \mathrm{mg} / 100 \mathrm{~g}$. Penambahan sari buah naga merah yang semakin tinggi akan meningkatkan konsentrasi betasianin pada Caspian Sea yoghurt. Proses fermentasi akan menurunkan pH yang dapat menjaga kestabilan betasianin dari kerusakan. Menurut Herbach et al. (2005) betasianin stabil pada $\mathrm{pH}$ kisaran 4 hingga 5 dengan adanya oksigen maupun dalam kondisi anaerobik.

\section{Karakteristik Fisik Caspian Sea Yoghurt Buah Naga Merah}

Karakteristik fisik Caspian Sea yoghurt berupa viskositas, total padatan terlarut, kecerahan $\left(\mathrm{L}^{*}\right)$, kemerahan $\left(\mathrm{a}^{*}\right)$, dan kekuningan $\left(\mathrm{b}^{*}\right)$, ditampilkan pada Tabel 4.

Tabel 4. Rerata Viskositas, Total Padatan Terlarut, Kecerahan $\left(\mathrm{L}^{*}\right)$, Kemerahan $\left(\mathrm{a}^{*}\right)$, dan Kekuningan ( $b^{*}$ ) Caspian Sea Yoghurt Buah Naga Merah

\begin{tabular}{|c|c|c|c|c|c|c|}
\hline $\begin{array}{l}\text { Lama } \\
\text { Penyimp } \\
\text { a-nan }\end{array}$ & $\begin{array}{c}\text { Konse } \\
\text { n-trasi } \\
\text { Sari } \\
\text { Buah } \\
\text { Naga }\end{array}$ & $\begin{array}{c}\text { Rerata } \\
\text { Viskositas } \\
\text { (cP) }\end{array}$ & $\begin{array}{c}\text { Rerata } \\
\text { Total } \\
\text { Padatan } \\
\text { Terlarut } \\
\text { ( }{ }^{\text {bbrix })}\end{array}$ & $\begin{array}{c}\text { Rerata } \\
\text { Keceraha } \\
\text { n L* }^{*}\end{array}$ & $\begin{array}{c}\text { Rerata } \\
\text { Kemerahan } \\
\mathbf{a}^{*}\end{array}$ & $\begin{array}{c}\text { Rerata } \\
\text { Kekuninga } \\
\mathbf{n} \mathbf{b}^{\star}\end{array}$ \\
\hline \multirow{3}{*}{0 hari } & $10 \%$ & $\begin{array}{c}386.7 \pm \\
15.28\end{array}$ & $\begin{array}{c}6.13 \pm \\
0.15\end{array}$ & $\begin{array}{c}64.33 \pm \\
0.64\end{array}$ & $\begin{array}{c}34.80 \pm \\
0.66\end{array}$ & $-8.67 \pm 0.40$ \\
\hline & $15 \%$ & $\begin{array}{c}366.7 \pm \\
20.82\end{array}$ & $\begin{array}{c}5.90 \pm \\
0.10\end{array}$ & $\begin{array}{c}59.00 \pm \\
0.56\end{array}$ & $\begin{array}{c}40.67 \pm \\
0.65\end{array}$ & $\begin{array}{c}-10.70 \pm \\
0.40\end{array}$ \\
\hline & $20 \%$ & $\begin{array}{c}310.0 \pm \\
0.00\end{array}$ & $\begin{array}{c}5.67 \pm \\
0.15\end{array}$ & $\begin{array}{c}50.73 \pm \\
0.70\end{array}$ & $\begin{array}{c}47.80 \pm \\
1.55\end{array}$ & $\begin{array}{c}-12.90 \pm \\
0.10\end{array}$ \\
\hline \multirow{3}{*}{4 hari } & $10 \%$ & $\begin{array}{c}420.0 \pm \\
40.00\end{array}$ & $\begin{array}{c}6.27 \pm \\
0.25\end{array}$ & $\begin{array}{c}61.17 \pm \\
1.29\end{array}$ & $\begin{array}{c}37.43 \pm \\
1.14\end{array}$ & $\begin{array}{c}-10.63 \pm \\
0.55\end{array}$ \\
\hline & $15 \%$ & $\begin{array}{c}385.0 \pm \\
25.00\end{array}$ & $\begin{array}{c}6.00 \pm \\
0.50\end{array}$ & $\begin{array}{c}56.05 \pm \\
0.94\end{array}$ & $\begin{array}{c}41.35 \pm \\
0.48\end{array}$ & $\begin{array}{c}-11.98 \pm \\
0.75\end{array}$ \\
\hline & $20 \%$ & $\begin{array}{c}350.0 \pm \\
34.64\end{array}$ & $\begin{array}{c}5.97 \pm \\
0.06\end{array}$ & $\begin{array}{c}51.33 \pm \\
1.85\end{array}$ & $\begin{array}{c}44.66 \pm \\
1.35\end{array}$ & $\begin{array}{c}-14.07 \pm \\
0.43\end{array}$ \\
\hline \multirow{3}{*}{8 hari } & $10 \%$ & $\begin{array}{c}536.7 \pm \\
25.17\end{array}$ & $\begin{array}{c}6.93 \pm \\
0.06\end{array}$ & $\begin{array}{c}59.41 \pm \\
1.67\end{array}$ & $\begin{array}{c}39.37 \pm \\
2.89\end{array}$ & $\begin{array}{c}-11.05 \pm \\
0.54\end{array}$ \\
\hline & $15 \%$ & $\begin{array}{c}486.7 \pm \\
15.28\end{array}$ & $\begin{array}{c}6.87 \pm \\
0.32\end{array}$ & $\begin{array}{c}56.12 \pm \\
1.37\end{array}$ & $\begin{array}{c}42.23 \pm \\
1.49\end{array}$ & $\begin{array}{c}-13.26 \pm \\
0.70\end{array}$ \\
\hline & $20 \%$ & $\begin{array}{c}446.7 \pm \\
5.77\end{array}$ & $\begin{array}{c}6.73 \pm \\
0.25\end{array}$ & $\begin{array}{c}53.45 \pm \\
0.68\end{array}$ & $\begin{array}{c}44.59 \pm \\
0.34\end{array}$ & $\begin{array}{c}-15.67 \pm \\
0.22\end{array}$ \\
\hline \multirow{3}{*}{12 hari } & $10 \%$ & $\begin{array}{c}760.0 \pm \\
51.96\end{array}$ & $\begin{array}{c}7.10 \pm \\
0.10\end{array}$ & $\begin{array}{c}64.10 \pm \\
2.16\end{array}$ & $\begin{array}{c}32.65 \pm \\
2.39\end{array}$ & $-9.12 \pm 1.01$ \\
\hline & $15 \%$ & $\begin{array}{c}573.3 \pm \\
23.09\end{array}$ & $\begin{array}{c}7.03 \pm \\
0.06\end{array}$ & $\begin{array}{c}56.05 \pm \\
1.87\end{array}$ & $\begin{array}{c}40.66 \pm \\
2.04\end{array}$ & $\begin{array}{c}-13.21 \pm \\
0.46\end{array}$ \\
\hline & $20 \%$ & $\begin{array}{c}556.7 \pm \\
25.17\end{array}$ & $\begin{array}{c}6.97 \pm \\
0.15\end{array}$ & $\begin{array}{c}51.80 \pm \\
1.74\end{array}$ & $\begin{array}{c}44.15 \pm \\
2.27\end{array}$ & $\begin{array}{c}-15.16 \pm \\
0.55\end{array}$ \\
\hline
\end{tabular}

\section{Viskositas}

Viskositas Caspian Sea yoghurt dengan perlakuan penambahan sari buah naga merah dan lama penyimpanan berkisar antara 310-760 cP. Semakin lama waktu penyimpanan, menyebabkan viskositas semakin meningkat. Protein mempengaruhi viskositas yoghurt karena dengan adanya proses fermentasi akan menyebabkan degradasi protein oleh terbentuknya asam, dan pada $\mathrm{pH}$ isoelektrik protein akan mengendap dan membentuk gel yoghurt (Sodini, et al., 2002). Menurut Hui et al. (2004) produksi 
eksopolisakarida oleh Lactococcus lactis ssp. cremoris juga mempengaruhi peningkatan viskositas. Hal itu karena eksopolisakarida berinteraksi dangan matriks protein menghasilkan ikatan yang lebih kuat dan meningkatkan kemampuan dalam mengikat air sehingga viskositas akan meningkat. Selain itu, adanya eksopolisakarida akan membuat Caspian Sea yoghurt tidak rentan mengalami sineresis.

\section{Total Padatan Terlarut}

Total padatan terlarut Caspian Sea yoghurt dengan perlakuan penambahan sari buah naga merah dan lama penyimpanan berkisar antara 5.67-7.10 ${ }^{\circ}$ brix. Total padatan terlarut akan semakin meningkat seiiring dengan semakin lama waktu penyimpanan. Menurut Yuliana dkk. (2013) metabolit asam laktat dan asam-asam organik yang diproduksi selama fermentasi akan terakumulasi, kemudian asam-asam organik bersama dengan total gula terlarut terhitung sebagai total padatan terlarut. Sintasari dkk. (2014) menambahkan bahwa sisa sukrosa, laktosa, dan asam-asam organik inilah yang akan terhitung sebagai total padatan terlarut.

\section{Kecerahan $\left(L^{*}\right)$}

Nilai kecerahan Caspian Sea yoghurt dengan perlakuan penambahan sari buah naga merah dan lama penyimpanan berkisar antara 50.73-64.10. Semakin tinggi konsentrasi buah naga merah yang ditambahkan, maka nilai kecerahan akan semakin menurun. Hal tersebut dikarenakan sari buah naga merah memiliki nilai kecerahan yang rendah berkisar antara 26.327.6, sehingga semakin banyak sari buah naga merah yang ditambahkan semakin rendah nilai kecerahan Caspian Sea yoghurt.

\section{Kemerahan $\left(a^{*}\right)$}

Nilai kemerahan Caspian Sea yoghurt dengan perlakuan penambahan sari buah naga merah dan lama penyimpanan berkisar antara 32.65-47.80. Konsentrasi buah yang tinggi akan meningkatkan kemerahan. Menurut Farida dkk. (2014) buah naga merah mengandung betasianin yang merupakan pigmen warna merah-violet. Konsentrasi betasianin pada buah naga merah yaitu sekitar $14.4 \mathrm{mg} / 100 \mathrm{~g}$. Semakin tinggi konsentrasi betasianin menyebabkan warna menjadi semakin merah.

\section{Kekuningan ( $\left.b^{*}\right)$}

Nilai kekuningan Caspian Sea yoghurt dengan perlakuan penambahan sari buah naga merah dan lama penyimpanan berkisar antara -8.67 hingga -15.67 . Menurut Widagdha dan Nisa (2015) warna kekuningan disebabkan oleh beta karoten yang terkandung dalam susu, beta karoten pada susu akan semakin tampak seiring dengan meningkatnya viskositas yoghurt. Namun, penambahan sari buah naga merah ini menutupi warna kekuningan yang dihasilkan sehingga warna yang terukur cenderung kebiruan.

\section{Karakteristik Organoleptik Caspian Sea Yoghurt Buah Naga Merah}

Uji yang digunakan untuk menganalisis karakteristik organoleptik Caspian Sea yoghurt adalah uji hedonik. Pada penelitian ini menggunakan 30 panelis tidak terlatih untuk mengetahui tingkat kesukaan Caspian Sea yoghurt. Karakteristik organoleptik meliputi parameter rasa, warna, aroma, dan kekentalan ditampilkan pada Tabel 5.

\section{Rasa}

Kesukaan panelis terhadap rasa Caspian Sea yoghurt sari buah naga merah berkisar antara 3.13 (netral) - 3.73 (agak suka). semakin lama waktu penyimpanan, rasa yoghurt akan semakin asam. Menurut Rahmawati dkk. (2015) selama fermentasi akan terbentuk asamasam organik dan jumlahnya akan semakin meningkat seiring dengan semakin lamanya waktu fermentasi. 


\section{Warna}

Kesukaan panelis terhadap warna Caspian Sea yoghurt sari buah naga merah berkisar antara 3.90 (agak suka) - 4.37 (suka). Hal itu dikarenakan semakin tingginya konsentrasi yang ditambahkan, maka warna Caspian Sea yoghurt akan semakin merah. Jadi, panelis lebih menyukai Caspian Sea yoghurt yang memiliki warna mencolok dibandingkan dengan kontrol yang memiliki warna putih hingga kekuningan.

Tabel 5. Rerata Skor Kesukaan Caspian Sea Yoghurt Buah Naga Merah (Uji Hedonik)

\begin{tabular}{cccccc}
\hline $\begin{array}{c}\text { Lama } \\
\begin{array}{c}\text { Penyimpana } \\
\mathbf{n}\end{array}\end{array}$ & $\begin{array}{c}\text { Konsentra } \\
\text { si Sari } \\
\text { Buah Naga }\end{array}$ & $\begin{array}{c}\text { Skor } \\
\text { Kesukaan } \\
\text { Rasa }\end{array}$ & $\begin{array}{c}\text { Skor } \\
\text { Kesukaan } \\
\text { Warna }\end{array}$ & $\begin{array}{c}\text { Skor } \\
\text { Kesukaan } \\
\text { Aroma }\end{array}$ & $\begin{array}{c}\text { Skor } \\
\text { Kesukaan } \\
\text { Kekentalan }\end{array}$ \\
\hline 0 hari & $10 \%$ & $3.63 \pm 0.56$ & $4.10 \pm 0.92$ & $3.47 \pm 1.04$ & $3.70 \pm 1.02$ \\
& $15 \%$ & $3.53 \pm 0.82$ & $4.17 \pm 0.65$ & $3.57 \pm 0.77$ & $3.50 \pm 0.78$ \\
& $20 \%$ & $3.47 \pm 1.14$ & $4.27 \pm 0.98$ & $3.67 \pm 0.92$ & $3.27 \pm 1.01$ \\
4 hari & $10 \%$ & $3.73 \pm 0.87$ & $3.93 \pm 0.94$ & $4.00 \pm 0.83$ & $3.77 \pm 0.82$ \\
& $15 \%$ & $3.57 \pm 0.90$ & $4.20 \pm 0.66$ & $3.90 \pm 0.80$ & $3.70 \pm 0.95$ \\
& $20 \%$ & $3.50 \pm 1.07$ & $4.37 \pm 0.81$ & $3.77 \pm 1.01$ & $3.43 \pm 0.90$ \\
8 hari & $10 \%$ & $3.43 \pm 0.94$ & $3.97 \pm 0.85$ & $3.60 \pm 0.81$ & $3.70 \pm 0.88$ \\
& $15 \%$ & $3.53 \pm 1.07$ & $4.10 \pm 0.71$ & $3.67 \pm 0.75$ & $3.53 \pm 1.14$ \\
& $20 \%$ & $3.50 \pm 0.94$ & $4.30 \pm 0.70$ & $3.63 \pm 1.03$ & $3.33 \pm 0.99$ \\
12 hari & $10 \%$ & $3.30 \pm 1.09$ & $3.90 \pm 0.92$ & $3.80 \pm 0.99$ & $3.43 \pm 1.14$ \\
& $15 \%$ & $3.13 \pm 1.25$ & $4.13 \pm 0.82$ & $3.70 \pm 0.95$ & $3.00 \pm 1.14$ \\
& $20 \%$ & $3.23 \pm 1.14$ & $4.03 \pm 1.03$ & $3.47 \pm 1.25$ & $2.83 \pm 1.21$ \\
\hline
\end{tabular}

\section{Aroma}

Kesukaan panelis terhadap aroma Caspian Sea yoghurt sari buah naga merah berkisar antara 3.47 (netral) - 4.00 (agak suka). Secara umum yoghurt memiliki aroma yang khas yaitu aroma asam. Selama fermentasi akan terbentuk senyawa-senyawa yang memberikan aroma dan rasa pada yoghurt yaitu asam-asam non volatil meliputi asam laktat, asam piruvat, asam oksalat dan asam-asam volatil meliputi asam formiat, asam asetat, asam propionat. Serta senyawa karbonil meliputi asetaldehida, diasetil (Malaka, 2007).

\section{Kekentalan}

Kesukaan panelis terhadap kekentalan Caspian Sea yoghurt sari buah naga merah berkisar antara 2.83 (netral) - 3.77 (agak suka). Semakin lama waktu penyimpanan Caspian Sea yoghurt sari buah naga merah, maka skor kesukaan terhadap kekentalan akan semakin menurun. Hal tersebut diduga saat melakukan uji sensori, sampel terlalu lama berada di suhu ruang sehingga dapat mempengaruhi kekentalan yoghurt. Menurut Aritonang (2010) suhu rendah akan memberikan pengaruh terhadap viskositas yoghurt yaitu dengan terbentuknya clumping (gumpalan) dari globula-globula lemak sehingga viskositas akan meningkat.

\section{Perlakuan Terbaik}

Metode perlakuan terbaik yang digunakan adalah metode Multiple Attribute (Zeleny 1982) menggunakan parameter organoleptik yaitu skor kesukaan rasa, warna, dan kekentalan. Perlakuan terbaik Caspian Sea yoghurt buah naga merah yang diperoleh adalah Caspian Sea yoghurt buah naga merah konsentrasi 10\% dan lama penyimpanan 0 hari.

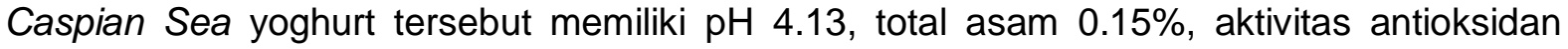
$25.68 \%$, konsentrasi betasianin $1.10 \mathrm{mg} / 100 \mathrm{~g}$, total bakteri asam laktat $5.17 \mathrm{log} \mathrm{cfu} / \mathrm{ml}$, viskositas $386.7 \mathrm{cP}$, total padatan terlarut 6.13 obrix, nilai kecerahan $\left(\mathrm{L}^{*}\right)$ 64.33, nilai kemerahan $\left(a^{*}\right) 34.80$, nilai kekuningan $\left(b^{*}\right)-8.67$, skor kesukaan rasa 3.63 , skor kesukaan warna 4.10, skor kesukaan aroma 3.47, dan skor kesukaan kekentalan 3.70. 


\section{SIMPULAN}

Perlakuan konsentrasi sari buah naga merah berpengaruh nyata $(\alpha=0,05)$ terhadap total bakteri asam laktat, aktivitas antioksidan, $\mathrm{pH}$, total asam, konsentrasi betasianin, kecerahan $\left(\mathrm{L}^{*}\right)$, kemerahan $\left(\mathrm{a}^{*}\right)$, kekuningan $\left(\mathrm{b}^{*}\right)$, dan parameter organoleptik meliputi warna dan kekentalan. Perlakuan lama penyimpanan berpengaruh nyata $(\alpha=0,05)$ terhadap total bakteri asam laktat, $\mathrm{pH}$, total asam, viskositas, total padatan terlarut, dan parameter organoleptik meliputi rasa dan kekentalan. Perlakuan terbaik Caspian Sea yoghurt buah naga merah adalah konsentrasi $10 \%$ dan lama penyimpanan 0 hari.

\section{DAFTAR PUSTAKA}

AOAC. 1990. Official Methods of Analysis of the Association of Official Analytical Chemistry. AOAC, Inc. Arlington

AOAC. 1995. Official Methods of Analysis of the Association of Official Analytical Chemistry. AOAC, Inc. Arlington

Apriyantono, A., Fardiaz, D., Puspitasari, N. L., Sedamawati dan Budiyanto, S. 1989. Analisis Pangan. PAU Pangan dan Gizi. IPB Press. Bogor.

Aritonang, S. 2010, Susu dan Teknologi. Swagati Press. Cirebon.

Farida, A., Holinesti, R., dan Syukri, D. 2014. Identifikasi Pigmen dari Kulit Buah Naga Merah (Hylocereus polyrhizus). Universitas Andalas. Padang.

Hui, Y. H., Goddik, L. M., Hansen, A. S., Josephsen, J., Nip, W. K., Stanfield, P. S., and Toldra, F. 2004. Handbook of Food and Baverage Fermentation Technology. Marcel Dekker, Inc. New York.

Kumalasari, K. E., Legowo, A. M., dan Al- Baarri, A. N. 2013. Total Bakteri Asam Laktat, Kadar Laktosa,pH, Keasaman, Kesukaan Drink Yogurt dengan Penambahan Ekstrak Buah Kelengkeng. Jurnal Aplikasi Teknologi Pangan 2:4, 165-168.

Lay, W.B. 1994. Analisis Mikroba di Laboratorium. Edisi I. PT. Raja Grafindo Persada. Jakarta.

Legowo, A.M., Kusrahayu dan Mulyani, S. 2009. Ilmu dan Teknologi Susu. Badan Penerbit Universitas Diponegoro. Semarang.

Malaka. 2007. Ilmu dan Teknologi Pengolahan Susu. Fakultas Peternakan. Universitas Hasanuddin. Makassar.

Nurul, S. R., and Asmah, R. 2014. Variability in Nutritional Composition and Phytochemical Properties of Red Pitaya (Hylocereus polyrhizus) from Malaysia

and Australia. International Food Research Journal 21:4, 1689-1697.

Paseephol, T., and Sherkat, F. 2009. Probiotic Stability of Yogurt Containing Jerusalem Artichoke Inulins DuringRefrigerated Storage. Journal of Functional Foods 1, 311318.

Phebe, D., Chew, M.K., Suraini, A. A., Lai, O. M., and Janna, O. A. 2009. Red- Fleshed Pitaya (Hylocereus polyrhizus) Fruit Colour and Betacyanin Content depend on Maturity. International Food Research Journal 16, 233-242.

Purwanti, E. 2015. Pembuatan Minuman Fermentasi Kombucha dari Buah Naga Merah (Hylocereus polyrhizus). Skripsi. UB. Malang.

Rahmawati, I. S., Zubaidah, E., dan Saparianti, E. Evaluasi Pertumbuhan Isolat Probiotik (L. casei dan L. plantarum) dalam Medium Fermentasi Berbasis Ubi Jalar (Ipomoea batatas L.) Selama Proses Fermentasi. Jurnal Aplikasi Teknologi Pangan 4:4, 133141.

Setianto, Y., Yoyok, P., dan Sri, M. 2014. Nilai pH, Viskositas, dan Tekstur Yoghurt Drink dengan Penambahan Ekstrak Salak Pondoh (Salacca zalacca). Jurnal Aplikasi Teknologi Pangan 3:3, 110-113.

Sintasari, R., Kusnadi, J., dan Ningtyas, D. W. Pengaruh Penambahan Konsentrasi Susu Skim dan Sukrosa terhadap Karakteristik Minuman Probiotik Sari Beras Merah. Jurnal Pangan dan Agroindustri 3:2, 65-75. 
Sodini, I., Lucas, A., Oliveira, M. N., Remeuf, F., and Corrieu, G., 2002. Effect of Milk Base and Starter Culture on Acidification, Texture, and Probiotic Cell Count in Fermented Milk Processing. J Dairy Sci. 85: 2479-2488.

Sunarlim, R., dan Usmiati, S. 2006. Sifat Mikrobiologi dan Sensori Dadih Susu Sapi yang di Fermentasi Menggunakan Lactobacillus plantarum dalam Kemasan yang Berbeda. Buletin Peternakan 30, 208216.

Tranggono, S., Sutardi, Haryadi, Suparno, A., $\quad$ Murdiyanti, S., Sudarmadji, K., Rahayu, S., Naruki, M., dan Astuti. 1990. Bahan Tambahan Makanan (Food Additive). Pusat Antar Universitas Pangan dan Gizi. Universitas Gajah Mada. Yogyakarta.

Usmiati, S. 2011. Karakteristik Dadih Susu Sapi yang Menggunakan Starter Bakteri Probiotik. JITV 16:2,140-152.

Virtanen, T. 2006. Development of Antioxidant Activity in Milk Whey During Fermentation with Lactid Acid Bacteria. MTT Agrifood Research. Finland.

Watts, B.M., Ylimaki, G.L., Jeffery, L. E., and Elias, L. G. 1989. Basic Sensory Methods for Food Evaluation. International Development Research Centre, Ottawa.

Widagdha, S., dan Nisa., F. C. 2015. Pengaruh Penambahan Sari Anggur (Vitis vinifera L.) dan Lama Fermentasi Terhadap Karakteristik Fisiko Kimia Yoghurt. Jurnal Pangandan Agroindustri 1:3, 248-258.

Wu, L. C., Hsu, H., Chen, Y., Chiu, C., Yu-In, L., Y. And Annie, H, J. $2006 . \quad$ Antioxidant and Antiproliferative Activities of Red Pitaya. Food Chemistry 9,:319-327.

Yuliana, N. S., Nurdjanah, dan Margareta, M. 2013 The Effect of Mixed Starter Culture of Lactic Acid Bacteria on The Characteristic of Pickled Orange- Fleshed Sweet Potato (Ipomea batatas L.). Microbiology Indonesia 7:1, 1-8.

Yuwono, S., dan Susanto. 1998. Pengujian Fisik Pangan. Jurusan Teknologi Hasil Pertanian. Fakultas Teknologi Pertanian. Universitas Brawijaya. Malang.

Zeleny, M. 1982. Multiple Criteria Decision Making. McGraw-Hill. New York.

Zhang, S. 2011. Antioxidative Activity of Lactic Acid Bacteria in Yoghurt. African Journal of Microbiology Reseach 5:29, 5194-5201. 